\title{
Chrysojasminum, a new genus for Jasminum sect. Alternifolia (Oleaceae, Jasmineae)
}

\section{Enrico Banfi}

Sezione di Botanica, Museo di Storia Naturale di Milano, Corso Venezia 55, 20121 Milano, Italia.

E-mail: enrbanfi@yahoo.it

\begin{abstract}
Recent phylogenetic investigations about Jasminum s.1. have shown that species possessing both alternate leaves and yellow flowers (sect. Alternifolia) constitute a clade (monophylum) that is sister to all the other sections of the genus or even to Jasminum itself plus the American/South African genus Menodora. Such evidence sets the need to revise the generic delimitation of Jasminum by establishing a separate genus for the species belonging to sect. Alternifolia. As a consequence, the new genus Chrysojasminum is here established and the relevant nomenclatural combinations are supplied for fifteen taxa.
\end{abstract}

Riassunto - Chrysojasminum, un nuovo genere per Jasminum sect. Alternifolia (Oleaceae, Jasmineae).

Recenti indagini filogenetiche sulle Jasmineae e, in particolare, sul genere Jasminum s.l. hanno dimostrato come le specie provviste di foglie alterne e fiori gialli, correntemente attribuite alla sezione Alternifolia, costituiscano un gruppo monofiletico. Tale clado appare consistente in entrambe le topologie risultanti dall'analisi filogenetica, presentandosi in una sister del clado formato dalle altre sezioni di Jasminum (con Menodora sister di Jasminum), nell'altra addirittura sister di Menodora + Jasminum.

Si rende dunque necessaria la separazione della sect. Alternifolia in un proprio genere, il quale, non disponendo di nomi nella letteratura, viene qui istituito ex novo assieme alle relative, necessarie combinazioni nomenclaturali per le specie.

Key-words: Jasminum, phylogeny, new genus, nomenclatural combinations.

\section{INTRODUCTION}

So far as known, the genus Jasminum L., depending on the authors' delimitation, includes about 200 species ranging from Europe, Africa, Asia, Pacific Islands to Australia (Green \& Miller, 2009). Together with the approximately 30 American and South African species of Menodora Bonpl., they constitute a descent (monophylum) in the family Oleaceae identified by the tribe Jasmineae Lam. \& DC. (Wallander \& Albert, 2000). The literature is rather poor on the relationships between these two genera, the most significant contribution being due to Rohwer (1997), who investigated the fruit morpho-functional features in Jasminum mesnyi (sect. Primulina) and Menodora species. Regarding the in- frageneric diversity, the current belief about Jasminum taxonomy attributes to this genus five sections recognized on the basis of morphological features, namely sect. Jasminum (= Pinnatifolia DC.), Trifoliolata DC., Unifoliolata DC., Primulina P.S.Green (= Nudiflora Tzvelev, nom. illeg.) and Alternifolia DC. The first three appear not clearly delimited one from another, nor free from artificiality (Green \& Miller, 2009) because the number of leaf segments (leaflets), on which they are founded, is an inconstant and homoplastic character. On the contrary, the never yellow corolla (white or reddened to various extent) identifies a synapomorphic condition over these sections.

Sect. Primulina (2 species) is marked by some consistent characters, the most obvious of which being the yellow corolla combined with opposite leaves.

A biomolecular approach to the phylogeny of Jasminum was developed in the cited paper of Wallander \& Albert (2000), where authors, based on RPS16 and TRNL-F loci sequence data, found a complete monophyly for the tribe Jasmineae (jackknife value: 100) that turned out sister (jackknife value: 76) to the tribe Oleeae. Inside the tribal monophylum they have shown that Jasminum sect. Alternifolia (where the type name species $J$. humile L. is included in the analysis), with a jackknife value of 100 , results clearly sister to Menodora + other species of $\mathrm{Ja}$ sminum including, besides members of the sections Trifoliolata (J. fluminense Vell., J. sinense Hemsl.) and Unifoliolata (J. laurifolium Roxb. ex Hornem. f. nitidum (Skan) P.S.Green), the type name species and the type species, respectively, of sections Primulina (J. nudiflorum Lindl.) and Jasminum (J. officinale L., that is obviously the type species also for the genus).

Lee et al. (2007) have highlighted the existence of important gene relocations in the Jasminum and Menodora chloroplast genome, derived from multiple overlapping inversions and they have shown that such relocations mark phylogenetic steps in the evolution of the tribe Jasmineae. They also dated each step correlatedly with the occurrence of synapomorphies that are relevant to sections and genera. It is true that in this work the 
sampling was extended to a quite small number of species (1 Unifoliolata: J. simplicifolium G.Forst. subsp. simplicifolium and subsp. le-ratii (Schltr.) P.S.Green, 1 Trifoliolata: J. abyssinicum Hochst. ex DC., 2 Primulina: $J$. mesnyi Hance and the type name species $J$. nudiflorum Lindl., 2 Alternifolia: $J$. fruticans L. and $J$. subhumile W.W.Sm. and 2 Menodora: M. longiflora Engelm. ex A.Gray, M. scabra A.Gray), however reliability and phylogenetic significance of the investigated genomic features are strong enough, with jackknife values never $<100$, to allow us to exclude that in the future more extensive investigations on Jasminum and Menodora diversity will change the outlines surfaced in the present phylogenetic framework. Finally, it is worth to remind the paper of Kim \& Kim (2011) on Forsythieae phylogeny, where, besides focusing evolutionary relationships in Abeliophyllum, Forsythia and remaining Oleaceae, Fontanesia turns out significantly closer to Jasmineae than to any other tribe in the family.

Quite certainly the sections of Jasminum, Unifoliolata and Trifoliolata must be reconducted to the nominal sect. Jasminum, while the sect. Primulina, as shown by Lee et al. (2007), is sister to the former one. With regard to Menodora, this genus results differently placed in two topologies, that is a) sister to the section $\mathrm{Al}$ ternifolia with which it constitutes the sister group of Jasminum + Primulina and b) sister to Jasminum + Primulina, both sister to the section Alternifolia; in any case, Alternifolia clearly shows not being subordinated to Jasminum + Primulina. Even if future investigations on the former section Pinnatifida (not treated in the paper of Lee et al., 2007), consisting of few species among which the genus type $J$. officinale L., will demonstrate the need to make changes to the taxonomy of white flowered jasmins, neither sect. Primulina nor, least of all, sect. Alternifolia and Menodora will be affected by this issue.

Therefore, according with phylogenetic data, two alternative solutions can be proposed: 1) including Menodora in Jasminum and keeping four sections in the genus: Jasminum, Primulina, Alternifolia and Menodora, 2) establishing a new genus to raise Alternifolia, that, together with Jasminum (2 sections) and Menodora, will outline the tribe Jasmineae.

Between these options, I definitely choose the second one because merging Menodora into Jasminum is not advisable, the former representing a very consistent evolutionary lineage that has diverged from Jasminum also geographically. It doesn't seem possible to find in literature denominations that are recoverable at the genus rank for Jasminum sect. Alternifolia. Therefore it becomes necessary to estabilish a new genus name.

Chrysojasminum Banfi, gen. nov.

三 Jasminum L. sect. Alternifolia DC., Prodr. 8: 312. 1844.

Typus: Jasminum humile L., Sp. Pl. 1: 7. 1753., here designated also for the section Alternifolia on the base of the type name, as indicated in The International Plant Name Index
Etymology: Chryso from the greek $\chi \rho v \sigma o ́ \varsigma$ (latin: $a u-$ rum), gold and jasminum, jasmin, referring to the colour of the flower.

From Jasminum, Chrysojasminum is distinguished by the alternate leaves, from Menodora by the valvate corolla lobes.

\section{New combinations}

Fifteen nomenclatural combinations are here established with the indication of basionyms; a complete synonymy for each taxon was done by Green (1961) to which readers are referred. This should explain the fact that the author of the present paper agrees with those who don't like a too enlarged species concept when different infraspecific units, even if constituting together a monophylum, show each a definite morphological, biogeographical (allopatric) and ecological consistency. In my opinion, for such taxa, the species rank seems to be the most suitable choice bio-ecogeographically acceptable and taxonomically practical. We shall really ask ourselves how, in these cases, we think to be able to identify the exact completion degree reached by a taxon along its historical differentiation to which a definite infraspecific rank may be applied.

Sometimes I believe that it is better to refer just to the species rank than trying to adapt to the case an infraspecific rank without a suitable and objective support. Lowest infraspecific ranks (variety and form) are usefully applied to the weakest component of the variation to represent the internal species diversity and supply a concrete taxonomical representation as a whole, but a large use of the subspecies rank often betrays an excess of interpretative caution, right where recognizing a species seems to be just a plausible and convincing issue. The choice of the species rank, here regarding just a single case, is further supported by the fact that the subspecific taxon involved (J. odoratissimum subsp. goetzeanum) is largely allopatric and well isolated from its nominal relative, the subsp. odoratissimum being indeed endemic to Macaronesia (Madeira and Tenerife) whereas the subsp. goetzeanum occurs in tropical Africa.

Chrysojasminum bignoniaceum (Wall. ex G.Don) Banfi, comb. nov.

三 Jasminum bignoniaceum Wall. ex G.Don, Gen. Hist. 4: 63. 1837-1838.

subsp. bignoniaceum

subsp. zeylanicum (P.S.Green) Banfi

$\equiv$ Jasminum bignoniaceum Wall. ex G.Don subsp. zeylanicum P.S.Green, Kew Bull. 40: 229. 1985.

Chrysojasminum floridum (Bunge) Banfi, comb. nov. 三Jasminum floridum Bunge, Enum. Pl. Chin. Bor. [A.A. von Bunge]: 42.1833.

Chrysojasminum fruticans (L.) Banfi, comb. nov. 三Jasminum fruticans L., Sp. Pl. 1: 7. 1753. 
Chrysojasminum humile (L.) Banfi, comb. nov. (Fig. 1) $\equiv$ Jasminum humile L., Sp. Pl. 1: 7. 1753.

var. humile

f. humile

f. farreri (Gilmour) Banfi, comb. nov.

$\equiv$ Jasminum farreri Gilmour, Bot. Mag. 157: t. 9351. 1934.

$\equiv$ Jasminum humile L. f. farreri (Gilmour) P.S.Green, Trees and Shrubs Brit. Isl. ed. 8, 2: 465. 1976.

f. wallichianum (Lindl.) Banfi, comb. nov.

$\equiv$ Jasminum wallichianum Lindl., Edward's Bot. Reg. 17: t. 1409. 1831.

三Jasminum humile L. f. wallichianum (Lindl.) P.S.Green, Baileya 1: 148. 1965.

var. microphyllum (Chia) Banfi, comb. nov.

$\equiv$ Jasminum humile L. f. microphyllum Chia, Acta Phytotax. Sin. 2: 27. 1952.

$\equiv$ Jasminum humile L. var. microphyllum (Chia) P.S.Green, Notes Roy. Bot. Gard. Edinburgh, 23 (3): 370. 1961

Chrysojasminum leptophyllum (Rafiq) Banfi, comb. nov. 三 Jasminum leptophyllum Rafiq, Novon 6: 295-297. 1996.

Chrysojasminum odoratissimum (L.) Banfi, comb. nov. $\equiv$ Jasminum odoratissimum L., Sp. Pl. 1: 7. 1753 .
Chrysojasminum goetzeanum (Gilg) Banfi, comb. nov.

三Jasminum goetzeanum Gilg, Bot. Jahrb. Syst. 28 (4): 451. 1900 .

三 Jasminum odoratissimum L. subsp. goetzeanum (Gilg) P.S.Green, Notes Roy. Bot. Gard. Edinburgh, 23(3): 375. 1961.

Chrysojasminum parkeri (Dunn) Banfi, comb. nov.

三Jasminum parkeri Dunn, Bull. Misc. Inform. Kew, 1920: 69. 1920.

Chrysojasminum stans (Pax) Banfi, comb. nov.

三Jasminum stans Pax in Engler, Bot. Jahrb. Syst. 39: 641. 1907.

Chrysojasminum subhumile (W.W.Sm.) Banfi \& Galasso, comb. nov.

三 Jasminum subhumile W.W.Sm., Notes Roy. Bot. Gard. Edinburgh 8: 127. 1913.

var. subhumile

var. glabricymosum (W.W.Sm.) Banfi \& Galasso, comb. nov.

$\equiv$ Jasminum heterophyllum Roxb. var. glabricymosum W.W.Sm., Notes Roy. Bot. Gard. Edinburgh 12 (59): 209. 1920, nec J. taiwanianum Masam., J. Soc. Trop. Agric. 2: 152. 1930.

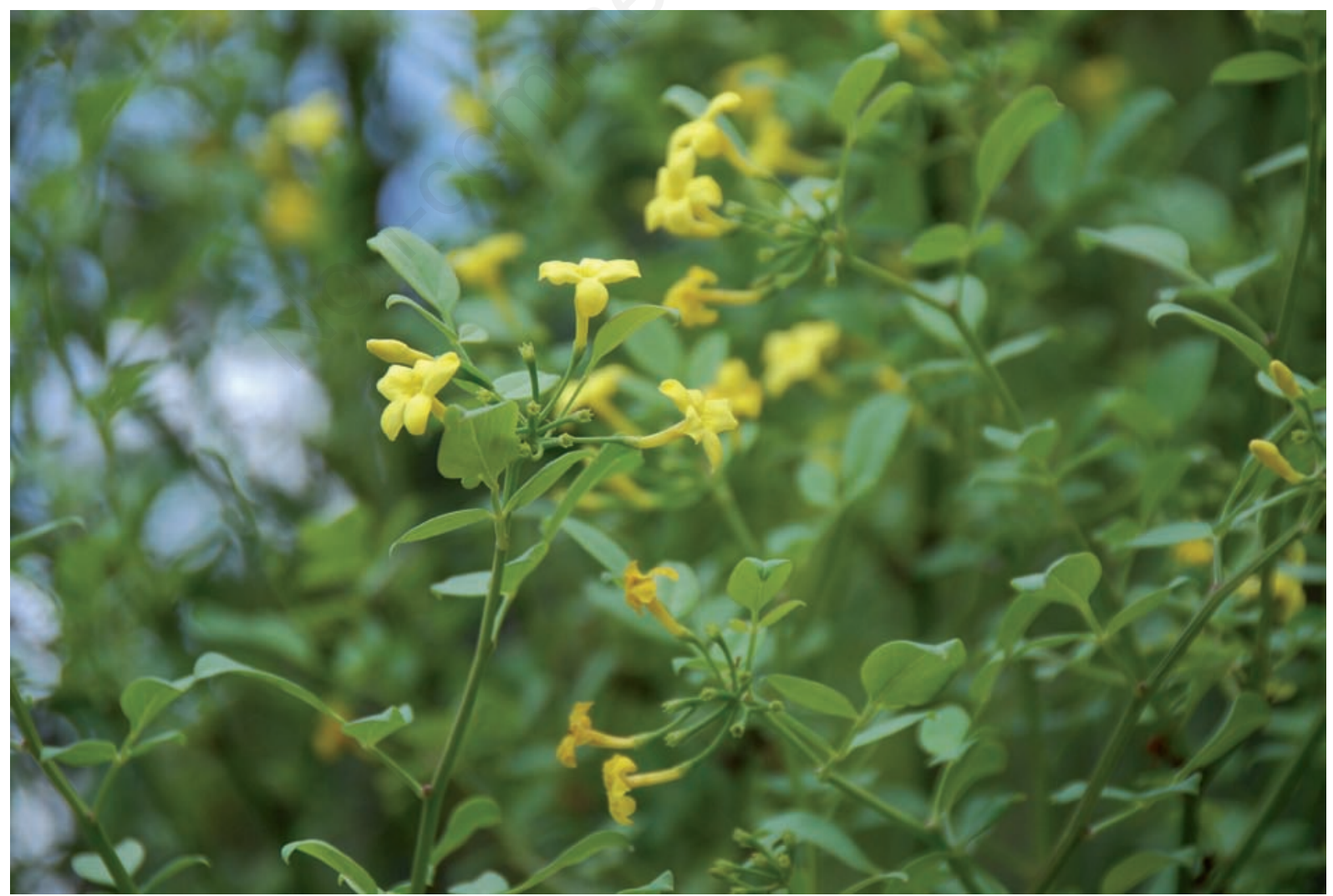

Fig. 1 - Chrysojasminum humile, the type species of the genus (Photo E. Banfi). 


\section{REFERENCES}

Green P. S., 1961 - Studies in the genus Jasminum I: section Alternifolia. Notes from the Royal Botanic Garden, Edinburgh, 23 (3): 355-384.

Green P. S. \& Miller D., 2009 - The genus Jasminum in cultivation. Royal Botanic Gardens, Kew, Richmond, Surrey.

Kim D.-K. \& Kim J.-H., 2011 - Molecular phylogeny of tribe Forsythieae (Oleaceae) based on nuclear ribosomal DNA internal transcribed spacers and plastid DNA trnL-F and matK gene sequences. Journal of Plant Research, 124 (3): 339-347(9).

Lee H.-L., Jansen R. K., Chumley T. W. \& Kim K.-J., 2007 - Gene relocations within chloroplast genomes of Jasminum and Menodora (Oleaceae) are due to multiple, overlapping inversions. Molecular Biology and Evolution, Oxford, 24 (5): 1161-1180.
Rohwer J. G., 1997 - The fruits of Jasminum mesnyi (Oleaceae), and the distinction between Jasminum and Menodora. Annals of the Missouri Botanical Garden, 84: 848-856.

The International Plant Name Index (IPNI). http://www. ipni.org/index.html

Wallander E. \& Albert V. A., 1997 - Phylogeny and classification of Oleaceae based on rps 16 and trnL-F sequence data. American Journal of Botany, 87: 18271841. 